\title{
JØDER OG ANDRE DANSKERE Den nyere antisemitismeforskning og dens implikationer for dansk historieskrivning: En forskningsoversigt
}

\author{
THORSTEN WAGNER \\ Berlin / København
}

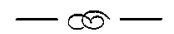

ABSTRACT Due to the national narrative of successful integration of Danish Jews and their heroic rescue from Nazi persecution, a critical investigation of the relationship between Jews and Non-Jews in Igth and 2oth century Danish society has been neglected until recently. The article discusses recent developments in the field of antisemitism studies and their applicability in such an undertaking. The re-evaluation of the continuous impact of religious Jew-hatred even on "modern" forms of antisemitism as well as a new appreciation of the cultural dimension of anti-Jewish stereotyping have been instrumental in a new understanding of antisemitism. Together with a growing awareness of the interrelationship between the construction of the nation and the politics of exclusion, these trends have created new grounds for historical research. It is argued that this new generation of research also calls for a rewriting of Danish history "from the margins": The liberal democratic political culture that informed the formation of the Danish nation state did not do without exclusionist practices; on the contrary, it implied a rejection of cultural or ethnic heterogeneity. Instead of exonerating Danish antisemitism by self-serving comparisons, a fresh view on Danish-Jewish relations in modern times promises new insights into the development of Danish national identity, oscillating between inclusion and exclusion.

\section{ANTISEMITISME - ET NYT EMNE FOR DANSK FORSKNING}

Historiske forhold, der ikke har betydning, behøver man heller ikke at forske i. På dette grundlag har også generationer af danske historikere været enige $i$, at jødehad og antisemitisme ikke var relevante 
emner i en dansk sammenhæng - med undtagelse af at fraværet af samme blev anset som årsag til redningsaktionen i oktober 1943. Denne manglende interesse gjaldt - og gælder delvist stadig - både for antisemitismen i det danske samfund og for andre landes antisemitisme. Dertil kommer, at en betragtelig del af dansk historiografi stadig opererer inden for nationalstatens historietradition og derfor kun interesserer sig begrænset for andre samfunds historiske problemer eller for komparative tilgangsvinkler. Dette nationalt-snævre perspektiv er ikke et særtræk ved dansk historievidenskab; men kombineret med en bred konsensus om, at antisemitismen både var og er fremmed for "dansk mentalitet", resulterer denne konstellation i en manglende interesse for en central dimension af den vestlige verdens historie. Selv den nyere danske historieforskning har således kun i et begrænset omfang formået at frigøre sig fra den konstruktion af polariserede, nationale myter, der sætter det demokratiske og liberale Danmarks værdisæt og normer op imod "udanske" fænomener som fremmedhad og antisemitisme. En af farerne ved sådanne konstruktioner af entydige historiebilleder er, at de har tendens til at tilsløre i stedet for at forklare, til at simulere nemme og opportune svar i stedet for at rejse nye kritiske spørgsmål til historien og dennes konsekvenser for kollektive identiteter. De første undersøgelser af jødehadet og antisemitismen $i$ en dansk sammenhæng peger imidlertid på, at disse fænomener udgør et centralt aspekt af dansk historie, og at forholdet mellem jødiske og kristne danskere bidrager væsentligt til en øget forståelse af det danske samfunds historiske udvikling som helhed. ${ }^{1}$ Vil man tage fat på de talrige lakuner i dette forskningsfelt, er der brug for en afklaring af jødehad og antisemitisme som historiografiske analysekategorier. Både med hensyn til metodisk-teoretisk refleksion og empiriske studier står dansk historieforskning i denne henseende på bar bund. Denne mangel bliver endnu mere beklagelig i kraft af, at en sådan udforskning af jødehadets førmoderne og moderne udtryksformer i Danmark jo er en dimension af et bredere forskningsfelt, der ligeledes er præget af talrige lakuner: forholdet mellem jøder og ikke-jøder i Danmark i historisk perspektiv. Derudover er en afklaring af antisemitismens betydning for det danske samfunds historie selvfølgelig også en afgørende forudsætning for at kunne gå et skridt videre og tage fat på komparative stu- 
dier, der ikke nøjes med overilet at konstruere modsætningsforhold mellem nationers grad af antisemitisme. ${ }^{2}$

Hensigten med dette bidrag er ikke at gøre et forsøg på at fremlægge en begrebshistorisk undersøgelse eller en "endegyldig" definition af antisemitismen som historisk problem. ${ }^{3}$ Snarere skal der her fokuseres på antisemitismen som en analysekategori i den internationale og især den tyske forskning, der har været meget i bevægelse i de sidste år. I denne sammenhæng er definitionsproblemet imidlertid ikke til at overse: Begrebet er ofte enten blevet defineret så vidtfavnende, at det har tabt enhver analytisk brugbarhed, eller så snævert, at den pågældende forskningsgenstand - det være sig et konfessionelt samfund, en nation eller en erhvervsgruppe - har kunnet frikendes for at være befængt med dette ubehagelige fænomen. ${ }^{4}$ En kritisk vurdering af disse forskningshistoriske konjunkturer og deres stimulerende og problematiske tendenser synes at være en vigtig forudsætning for en dansk antisemitismeforskning i begyndelsesfasen. Jeg vil tage afsæt i nogle generelle betragtninger om antisemitismeforskningens udvikling, og på denne baggrund skitsere 1970ernes og 1980ernes dominerende forskningstradition, som man måske kunne betegne som det "socialhistoriske paradigme". Efterfølgende vil jeg diskutere fire forskellige tendenser, der især i løbet af r99oerne har udfordret dette paradigmes dominans: Analysen af antisemitismen som kulturel kode for et specifikt segment af befolkningen; en revurdering af det religiøse jødehads vedvarende betydning i det 19. og 20. århundrede; antisemitismen som prisme for en moderne kulturhistorie; og sluttelig relationen mellem nationens konstruktion og jødernes eksklusion. Diskussionen af disse fire nye tilgangsvinkler munder ud i et forsøg på at formulere en række teser angående denne forsknings implikationer og konsekwenser for en dansk antisemitismeforskning.

\section{DE FøRSTE ̊̊RTIER}

Bortset fra tysk nazistisk forskning i "bevægelsens" historiske rødder var det primært jødiske forskere i USA, Storbritannien, Frankrig og Israel, der i løbet af r940erne begyndte at udforske antisemitismens historie. Men ikke så overraskende fokuserede de på jødehadets historie i tysk kultur og samfundsliv. ${ }^{5}$ Først efter det historiografiske 
paradigmeskifte i midten af 196oerne, der var knyttet til den socialhistorisk orienterede, såkaldte Bielefeld-skoles voksende betydning, kom der også bevægelse i den (vest-)tyske forskning. ${ }^{6}$ Ønsket om at finde frem til de afgørende årsager, til at nationalsocialismen kunne komme til magten, konstituerede en vigtig drivkraft for denne historikergeneration, og en sådan motivation, at ville afklare, "hvordan det kunne ske", førte til et fokus i forskningen, der pointerede den tyske antisemitismes specielle eller endda exceptionelle karakter. ${ }^{\text {? }}$

I løbet af I980erne kunne der en overgang konstateres en aftagende forskningsinteresse for antisemitismen. Denne udvikling hang dels sammen med, at fascinationen af Sonderwegs-tesen ligeledes var aftagende, ${ }^{8}$ dels bundede den $i$, at en ny generation af forskere begyndte at fokusere på andre dimensioner af Holocausts forhistorie. En tredje faktor, der bidrog til denne reorientering, var fremkomsten af en ny, selvbevidst tysk-jødisk historieforskning, der ikke længere var villig til at acceptere et perspektiv, der gjorde jøderne til historiens passive objekter, udsat for antisemitisme og assimilationspres. Europæisk-jødisk historie skulle ikke længere reduceres til en apologetisk understregning af jødernes "bidrag" til de respektive nationale kulturer eller til en opremsning af en lang række af lidelser og forfølgelser. Allerede Salo Baron havde i sit opgør med det, han betegnede som the lachrymose conception of Jewish History, forkastet denne ensidige fokus på jøderne som ofre. ${ }^{10} \mathrm{Nu}$ begyndte en ny historikergeneration en konkret forskningsindsats for at genvinde et perspektiv, der også gav rum til undersøgelser af jøder som handlende individer i historien, med egne handlingsmønstre og strategier - altså som aktører med agency, for at bruge et lidt slidt historieteoretisk modebegreb. ${ }^{11}$

Men på trods af disse tendenser tyder intet på, at antisemitismen som genstand for historisk forskning på længere sigt er ved at tabe betydning eller aktualitet: Sålænge mordet på Europas jøder bliver tildelt betydningen som den centrale begivenhed i det 20 . århundredes tyske - og europæiske - historie, eller endda som det moderne samfunds skelsættende "civilisationsbrud", ${ }_{12}$ vil udforskningen af folkemordets årsager være en central udfordring for historieskrivningen. Som en vigtig faktor i Holocausts forhistorie vil antisemitismen udgøre en del af denne udfordring. ${ }^{13}$ 
Derudover er relationerne mellem jøder og ikke-jøder indlysende nok en central dimension af forskningen i moderne jødisk historie og disse relationer kan ikke forstås uden jødehad og antisemitisme som betydende kulturelle mønstre. Som en tredje forklaring kan der peges på aktuelle samfundspolitiske forhold: I kølvandet på den omfattende transformationsproces, der kulminerede i symbolet "I989", er de etnisk eller racistisk begrundede konflikter som bekendt for alvor vendt tilbage til Europa, og i denne udvikling indtager antisemitismen en central rolle både i Østeuropa og i Tyskland.

\section{DET SOCIALHISTORISKE PARADIGME}

Det var især socialhistorien som historiografisk skole eller måske endda paradigme, der dannede rammen om en omfattende og systematisk forskning i $1800-$ og 1900-tallets europæiske og især tyske antisemitisme. Denne tilgang indebar, at antisemitismens socio-økonomiske faktorer blev fremhævet på bekostning af idéhistoriske sammenhænge. ${ }^{14}$ De mest konsekvente fortolkninger af antisemitismens årsager og forløb gik endog ofte så vidt som til at reducere de "moderne" former for antisemitisk jødehad til et biprodukt af almene samfundskriser - kriser, der blev opfattet som følger af radikale transformationer af sociale og økonomiske strukturer. ${ }^{15}$ På mange måder svarede denne tendens selvfølgelig til de generelle metodiske kortslutninger i halvfjerdsernes og firsernes politiske socialhistorie, ikke mindst dens socio-økonomiske reduktionisme, der resulterede i en fokus på politikkens sociale grundlag og ikke sjældent definerede socio-økonomiske interesser som de altafgørende faktorer for politisk handling. At inddrage "kultur" i analysen betød i denne sammenhæng sjældent mere end at undersøge undervisningssektorens og kirkelivets organisatoriske strukturer. ${ }^{16}$

Men på trods af denne snævre socialhistoriske forståelse af antisemitisme, var denne forskning ikke desto mindre med til at lægge fundamentet for en moderne antisemitismeforskning. Tidligere årtiers værker havde - ikke sjældent på grundlag af en noget vag begrebsdannelse - konstrueret diverse traditionelt idéhistoriske forklaringer på antisemitismen som historisk fænomen. Først med den socialhistoriske antisemitismeforskning, især Reinhard Rürups skel- 
sættende studier fra sidst i I960erne, (som $1975 \mathrm{blev}$ publiceret samlet i antologien Emanzipation und Antisemitismus), ${ }^{17}$ blev sammenhængen mellem antisemitismens fremkomst og den samfundsmæssige udvikling som helhed undersøgt systematisk.

I modsætning til en tidligere fremherskende, både analytisk ufrugtbar og ahistorisk forestilling om et "evigt jødehad" som et kontinuerligt fænomen henover alle kulturelle skel, gjaldt det for disse historikere om at anskueliggøre, hvorledes samfundets radikale transformation fra slutningen af I700-tallet til og med det nittende århundrede skabte et "jødespørgsmål", som man ikke havde opfattet som et problem tidligere. Overgangen fra det feudale, korporative til det moderne, borgerlige samfund bevirkede således, at "jødespørgsmålet" i første omgang blev rejst med et emancipatorisk fortegn: Fordi de gamle sociale skel blev nedbrudt, trængte spørgsmålet sig på, hvordan jøder nu som ligeberettigede borgere skulle integreres i det nye, liberale samfund. Det er igen først og primært tyske forhold, som har været genstand for historisk forskning. Ikke mindst Reinhard Rürup har præsenteret et detaljeret billede af den tyske borgerligt-liberale bevægelses pinefulde og modsætningsfyldte vej frem mod at acceptere denne emancipation som en naturret, uden at knytte den til betingelser om akkulturation. ${ }^{18}$ Det varede mere end et halvt århundrede, førend flertallet af de tyske liberale var villige til at omsætte Christian Wilhelm von Dohms princip - at tilståelsen af borgerrettigheder er forudsætningen for borgerdyder, og ikke omvendt ${ }^{19}-$ til politisk handling. ${ }^{20}$

Først efter at denne emancipationsproces var nået langt, omend ikke fuldendt, og efter at denne transformationsproces var kommet i krise og dens borgerligt-liberale forkæmpere svækket, blev "jødespørgsmålet" rejst påny. Men denne gang blev det reformuleret på grundlag af en ny form for integrationsfjendtligt jødehad - den moderne antisemitisme. Jødehadets sociale og ideologiske forudsætninger havde ændret sig grundlæggende. Den klassiske socialhistoriske antisemismeforsknings centrale argument er således, at den moderne antisemitisme skal forstås som et grundlæggende postemancipatorisk fænomen. Antisemitismen udgør en reaktion mod en iværksat retslig ligestilling og social inklusion - og er dermed ikke et resultat af jøders gøren eller laden men er grundlæggende det mo- 
derne, borgerligt-kapitalistiske samfunds problem.

Potentielt byder denne fortolkningsramme på en yderligere analytisk styrke, idet den muliggør en forståelse af r80o-tallets antisemitisme, som er mindre afhængig af Sonderwegs-tesen, specielt i den vulgære version, der konstruerer en kontinuitetslinje i tysk historie "fra Luther til Hitler". Ved at fokusere på Tysklands modsætningsfyldte vej til et moderne, industrikapitalistisk samfund afstår den socialhistoriske tilgang således fra at indskrive antisemitismen i tysk historie som en integral, konstant og essentiel bestanddel. Snarere åbner den op for både en påskønnelse af de emancipatoriske potentialer i den tyske udvikling og en præcis analyse af de faktorer, der vanskeliggjorde en sådan emancipatorisk løsning på jødeproblemet. Dohms Bürgerliche Verbesserung var det første systematiske politiske program for en inklusion af jøderne i det nye borgerlige samfund - og samtidig var Tyskland det samfund, hvor den moderne antisemitisme for alvor fik samfundsmæssig betydning fra I870erne - på trods af ikke-tyske raceteoretikere som Gobineau og Chamberlain.

\section{TENDENSER I DEN NYERE FORSKNING}

Forskningen har i r98oerne og I99oerne dels taget udgangspunkt i halvfjerdsernes antisemitismeforskning, dels søgt at revidere tidligere fremgangsmåder og resultater væsentligt. Hvor dette kvantespring i antisemitismeforskningen, som den socialhistoriske tilgang betød, blev ignoreret, er resultaterne blevet derefter: Man behøver kun at se på forskere som Paul L. Rose, Daniel J. Goldhagen og John Weiss, som netop - til trods for forskellene imellem dem - alle opererer med en forestilling om et antisemitisk jødehad, der er dybt rodfæstet i tysk mentalitet og kultur i det mindste siden første halvdel af I800tallet - og som ovenikøbet mere eller mindre direkte fører til mordet på Europas jøder under Anden Verdenskrig: m.a.o. kontinuiteten fra Fichte til Himmler. ${ }^{21}$

I det følgende vil jeg derimod diskutere fire af de mest påfaldende tendenser $\mathrm{i}$ den nyere antisemitismeforskning, der peger fremad. Dog bør man nok indledningsvis understrege, at denne forskning først og fremmest har frembragt en ny mangfoldighed af emner og metoder. Vigtige projekter og værker har bl.a. undersøgt sammen- 
hængen mellem folkelig mobilisering og jødehad, især med hensyn til revolutionen i $1848 .^{22}$ Der er ligeledes blevet fokuseret på den antijødiske vold i det tyske samfund, der gik forud for nazismens antisemitiske praksis, blandt andet i Biedermeier- og Vormärz-tiden mellem 1815 og 1848 og under Weimarrepublikken. ${ }^{23}$ Flere forskere er begyndt at anlægge komparative synsvinkler, hvilket har ført til en ny forstålse af forskellige aspekter $\mathrm{i}$ antisemitismen. Ikke mindst har man sammenlignet antisemitismen og antikatolicismen, ${ }^{24}$ eller inddraget kønsdimensionen ved at belyse paralleller og kontraster mellem antisemitisme og antifeminisme $e^{25}$ eller ved at undersøge skønlitterære kvinde- og jødestereotyper. ${ }^{26}$ Derudover er forskningen blevet væsentligt mere opmærksom på den informelle, strukturelle eller institutionaliserede antisemitisme, som den kom til udfoldelse i universitetsmiljøet, i embedsmandsapparatet og forskellige professioner fra Kejserriget til med det Tredje Rige. ${ }^{27}$ Et andet nyt emne er antisemitisme og "Vergangenheitsbewältigung" i Vest- og især Østtyskland og sammenhængen med højreekstremismen: forskningens resultater har ikke mindst kunne pege på, hvorledes antizionismen i væsentlige træk har skabt rammen for antisemitismens vedvarende eksistens og nye opblomstring. ${ }^{28}$

Denne noget brogede liste formidler et indtryk af, hvorledes antisemitismeforskningen i de sidste årtier i stigende grad er kendetegnet ved et væsentligt bredere og mere varieret spektrum af tilgangsvinkler og genstande. I et overordnet perspektiv må man derudover konstatere et væsentligt, fælles træk i denne "diversificering" af forskningslandskabet: "Paradigmeskiftet" fra samfund til kultur i historievidenskaben har også haft vidtrækkende konsekvenser for forskningen i antisemitismens ansigter og rødder. Kulturelle, ideologiske og religiøse dimensioner rykkes stærkere i centrum og er blevet befriet fra determinismen i den socio-økonomiske reduktionisme. Endnu i 199I kunne Tony Kushner give udtryk for sin frustration over, at historikere, der forskede $\mathrm{i}$ antisemitisme, stadigt primært var fokuseret på traditionel politisk historie - og illustrerede endda denne modvilje mod andre tilgange ved at citere en kendt udtalelse - "noget" revet ud af sammenhængen: "Wenn ich das Wort Kultur höre, ziehe ich meinen Revolver" (Goebbels). ${ }^{29} \mathrm{Nu}$ fremgår det vel af det ovennævinte, at Kushners bebrejdelser ikke helt kan siges at galde for det social- 
historiske paradigme, der jo i sig selv repræsenterer en overvindelse af den klassiske politiske historieskrivnings mangler. Men den drastiske formulering peger alligevel på, at det primært er i løbet af rg9oerne, at antisemitismeforskningens nye tiltag fik gennemslagskraft.

\section{Antisemitismen som kulturel kode: Pioneren Shulamit Volkov}

Det var først og fremmest et banebrydende essay fra I978, der kom til at skabe nye parametre for firsernes og halvfemsernes forskningsdiskussion: Den israelske forsker Shulamit Volkov, (der ellers selv primært havde udmærket sig med en yderst solid, socialhistorisk orienteret ph.d.-afhandling om antisemitisme hos håndværksmestre), ${ }^{30}$ argumenterede her for antisemitismens funktion som integrationsfaktor for en antimodernistisk, konservativ subkultur i Kejserriget. Volkovs artikel åbnede op for en ny tilgang til det fortolkningsdilemma, der havde affødt en del debat i forskningen: På den ene side havde ansete forskere som Peter Pulzer og Werner Jochmann fremhævet antisemitismens fremtrædende betydning i Kejserrigets tyske samfund i årtierne før og efter 1900 . På den anden side kunne forskningen dårligt bortforklare den kendsgerning - som ikke mindst Richard S. Levy havde understreget - at den partipolitiske og organiserede antisemitisme før nationalsocialismen aldrig for alvor fik politisk betydning og på intet tidspunkt formåede at rekruttere mere end nogle få procent af befolkningen som medlemmer, vælgere og tilhængere.

Afgørende for, at Volkovs teser fik en så stimulerende indflydelse på forskningen og viste vejen frem, var at hun undgik at stirre sig blind på antisemitismen ved udelukkende at analysere denne som et isoleret ideologisk fænomen i et idé- eller organisationshistorisk perspektiv. I stedet valgte hun at opfatte antisemitismen som en central og integral del af bredere kulturelle mønstre, orienteringer og ideologier, der igen blev relateret til deres respektive miljøer. Dermed realiserede hun også bl.a. Werner Jochmanns appel om ikke at isolere antisemitismen men tværtimod analysere den som et indigent element i mere omfattende ideologiske verdensbilleder. Antisemitismens evne til at fungere som en integrerende kode, der viste sig at være kompatibel med specifikke sociale miljøers værdisæt og handlingsmønstre, kan i dette perspektiv bidrage til at forklare, hvorfor anti- 
semitismen kunne opnå en så stor betydning for samfundslag, der ikke (som for eksempel håndværksmestrene) kunne betegnes som "moderniseringstabere" - altså de befolkningsgrupper, der reelt eller i deres selvopfattelse blev dårligere stillet mht. deres sociale status som følge af det moderne industrisamfunds udvikling. Til sammenligning udgjorde de socio-kulturelle omvæltninger, der fulgte i kølvandet på den økonomiske krise og liberalismens transformation efter I870, ikke så meget en materiel trussel for "dannelsesborgerskabet", det tyske Bildungsbürgertum, som en udfordring for dets status og selvforståelse som samfundets sande og legitime elite.

Den forskning, som har ladet sig inspirere af Volkov, har bekræftet og yderligere nuanceret hendes teser. Den har ikke mindst demonstreret, at antisemitismen ofte udgjorde en bestanddel af en bredere Weltanschaung, der typisk var sat sammen af antisocialistiske, antidemokratiske, antiemancipatoriske og antifeministiske elementer. ${ }^{31}$ Det var netop dette væv af kulturelle orienteringsmønstre og dets vidtfavnende indflydelsessfære, der gav den dannelsesborgerlige antisemitisme, som Treitschke og hans meningsfæller propaganderede og praktiserede, gennemslagskraft.

Dette forhold tydeliggør også, at det på den ene side ikke er analytisk meningsfyldt at gøre enhver antijødisk bemærkning synonym med raceantisemitisme, men at det på den anden side ligeledes er dybt problematisk at bagatellisere den moderate, "respektable" antisemitisme: Før 1933 ramte det "gode selskabs" jødehad de tyske jøder meget hårdere end den radikale racistisk argumenterende antisemitisme. Netop denne dobbelte erkendelse burde der tages højde for i en fremtidig dansk antisemitismeforskning.

\section{Kontinuiteten rehabiliteres: Det religiøse jødehads vedvarende betydning}

Et væsentligt træk i de senere års forskning er, at den klare skillelinje mellem "traditionel", religiøs antijudaisme og moderne antisemitisme er blevet blødt op, og forskere i højere grad end hidtil har fokuseret på kontinuitetsmomentet $\mathrm{i}$ jødehadets praksis og ideologi. Men ikke nok med, at der er stor forskel på, i hvor høj grad denne kontinuitetens rehabilitering præger den historiske fortolkning, der er også tale om forskellige former for kontinuitet: Accentuerer man be- 
tydningen af de lange linjer især i den tyske historie eller pointeres jødehadets vedvarende kontinuitet generelt? Derudover bør man skelne mellem visse historikere, der understreger, at arven fra middelalderens antijudaisme har influeret 1800-tallets antisemitisme, og andre, der tyder nazistyrets antisemitiske terror- og mordpolitik som en følgerigtig og nærmest naturnødvendig konsekvens af den moderne antisemitismes opkomst i I87oernes Tyskland. Kontinuitet kan således i denne sammenhæng betyde flere ting.

Et nærmere blik på, hvordan denne revision af den rigide differentiering konkret udformer sig i teser og forskningsresultater, kan få kontinuitetstesens mangfoldighed til at træde endnu tydeligere frem. Således repræsenterede den ellers velansete israelsk sociolog og historiker Jacob Katz - ikke så overraskende - den mere konventionelle, zionistiske variant af kontinuitetstemaet. Han fortolker antisemitismen som den "evige", uundgåelige og principielle reaktion på jødisk diaspora-eksistens som sådan. ${ }^{32}$ Også Leni Yahils standardværk om oktober 1943 er præget af en nationaljødisk forstålse af det håbløse i diasporaens "assimilationisme": kendsgerningen, at selv de danske jøder - til trods for danskernes enestående redningsiver - blev konfronteret med jødehad, understreger for Yahil utvetydigt, at livet i diasporaen ingen steder kan garantere en virkelig normalisering underforstået, at det kan kun en hjemvenden til landet Israel..$^{33}$

Den nyere forskning har, afvigende fra denne zionistiske kontinuitetsforståelse, understreget kontinuiteten mellem det kristne jødehad og antisemitismen i det nittende og tyvende århundrede, især med hensyn til det katolske miljø. Disse forskningsbidrag har dog været af ret varierende kvalitet. Myriam Yardenis undersøgelse af relationen mellem jøder og ikke-jøder i det anseelige tidsrum fra 1500 til r8oo-tallet hører i den sammenhæng måske ikke til de mest overbevisende (Yardeni 1990). Christopher Clarks rammende vurdering af dette perspektiv kan også gøres gældende for en række publikationer med en lignende tilgangsvinkel: De løber let den risiko at fremkalde en forestilling om at

a fundamentally unchanging antisemitism has been creeping inexorably through the centuries, its progress interrupted only by occasional bouts of 'hibernation'. (Clark I99I, 994) 
Et vigtigt, men ligeledes ikke uproblematisk forskningsbidrag er James Harris' analyse af en folkelig petitionsbevægelse mod de bayerske jøders emancipation i 1849/50 (Harris 1994). Ligesom Dagmar Herzog $i$ hendes bog om konflikten mellem ultramontane konservative og antiklerikale liberale i Baden over definitionen af kristendom (og denne konflikts implikationer for [mænds!] seksuelle rettigheder og jødernes inklusion), lykkedes det Harris at illustrere jødehadets centrale betydning for udviklingen og politiseringen af et katolsk miljø. Dog formår Harris' forsøg på at fremdatere den moderne antisemitismes oprindelse ikke at overbevise: Der er ikke noget specielt "moderne" ved denne "antisemitismes" mediale kommunikationsform, idet den primært artikulerer sig i flyveskrifter og petitioner, og der ex stadig lang vej fra dens kombination af økonomiske og religiøse argumenter til senere årtiers dæmonisering og aggressivitet, ikke mindst i den radikale völkische antisemitisme fra århundredeskiftet til og med det Tredje Rige.

Ikke desto mindre har Herzogs, Harris' og især Olaf Blaschkes udforskning af den katolske antisemitisme tydeliggjort, at tesen om den moderne antisemitisme som et produkt af en sekulariseret protestantisme må relativeres: Katolicismen var langtfra immun over for den moderne form for antisemitisme, antijødiske religiøse traditioner bevarede ofte deres betydning og muterede under opkomsten af nye fordomsstrukturer til hybride, gammel-nye former for jødehad, og ofte udgjorde antisemitismen et centralt element $i$ et brydningsfelt, hvis konfliktlinier blev markeret af konfessionelle modsætninger mellem protestantisme, katolicisme og jødedom. I ideologi og praksis var antisemitismen $\mathrm{i}$ den sammenhæng ofte en funktion af de komplekse relationer mellem disse tre befolkningsgrupper, kausalt og diskursivt flettet sammen med andre negative stereotypiseringer og eksklusionsprocesser.

På denne baggrund bliver det åbenlyst, at antisemitismeforskningen må ses i sammenhæng med den nyere forskning om rekonfessionaliseringsprocesserne i det 19 . århundrede, der har påpeget, at forestillingen om en lineær fremadskridende sekularisering som det altoverskyggende mønster for 180o-tallets kulturelle og politiske udvikling grundigt må revideres: Meget taler for, at der i flere sammenhænge snarere var tale om en kompleks, interaktiv dialektik mellem 
religiøs fornyelse og sekularisering, neo-ortodoksi og antiklerikalisme. Nødvendigheden af at integrere disse religions- og kulturhistoriske forhold $i$ undersøgelsen af antisemitismen gælder især for ultramontanismen. Men også hvad angår den liberale kulturprotestantisme og dens halvhjertede og lunkne anti-antisemitisme må disse sammenhænge inddrages $i$ analysen, idet disse politisk og socialt ofte meget indflydelsesrige kredse hyppigt holdt fast ved forestillingen om et etnisk defineret folkebegreb og nødvendigheden af en afjudaisering af kristendommen. ${ }^{34}$

Et helt andet bud på kontinuitet er derimod Gavin Langmuirs tese om, at den "moderne antisemitisme" opstod i højmiddelalderen som reaktion på en gryende rationalisme og empirisme, og at I200tallets voldelige jødehad er nært beslægtet med den racistiske antisemitisme, der efter Stanford-professorens mening var den direkte og egentlige årsag til Holocaust. ${ }^{35}$ Den franko-canadiske historiker anlægger en religionshistorisk og socialpsykologisk synsvinkel, inddrager nyere teorier inden for konfliktforskningen og forskningen i fordomme og har gjort en indsats for en mere præcis definition af religion og religiøsitet som historiske fænomener. På denne baggrund og oprindelig med afsæt i en primær interesse i ritualmordsforestillingen - gør han et bemærkelsesværdigt forsøg på at definere tre forskellige former for jødehad efter deres respektive argumentationslogik frem for efter indholdsmæssige kriterier. ${ }^{36}$ Han skelner således mellem "realistiske" jødefjendtlige stereotyper, "xenophobical hostility" og "chimerical hostility" - som betegnelsen antyder, forudsætter sidstnævnte i modsætning til de to første ikke nogen "reel kerne", intet hold $\mathrm{i}$ "virkeligheden".

En af Langmuirs styrker er, at han fremfører gode argumenter for at skelne mellem antisemitisme og andre racistiske fordomme, og derudover gør han en indsats for at afkræfte den reduktionistiske forestilling, at jødehad først og fremmest er et udtryk for behovet for en syndebuk. Men Langmuirs kontinuitetskonstruktioner er ikke empirisk bæredygtige: de ignorerer de samfundsmæssige forandringer i høj- og senmiddelalderen, der havde vidtrækkende konsekvenser for forholdet mellem jøder og ikke-jøder. Uden kildemæssigt fundament postulerer historikeren en kontinuitet i antisemitismen helt frem til det 20. århundrede alene ved hjælp af den argumentative 
bro, at også nazismen er en religion - blot "fysiocentrisk" i modsætning til den "psykocentriske" kristendom. I forlængelse af denne tese placerer Langmuir sig ligeledes som radikal intentionalist $\mathrm{i}$ den kontroversielle debat om forholdet mellem ideologi og struktur som årsager til Holocaust uden dog at reflektere over denne stillingtagen og eller argumentere explicit for den.

Derimod har den unge historiker Olaf Blaschke med sine voluminøse publikationer, der repræsenterer gedigen historisk forskning på grundlag af et grundigt kildearbejde, også analytisk og metodisk sat en ny standard for antisemitismeforskningen ved at analysere antisemitismen som en kulturel kode, der binder katolicismen sammen. Han rekonstruerer katolicismen som "sozialmoralisches Milieu" (M. Rainer Lepsius) og etablerer en metodisk ramme for at analysere antisemitismens funktioner ved at operationalisere Lepsius' sociologiske begrebsapparat til brug for historisk forskning. ${ }^{37}$

En vigtigt resultat af denne tilgang er netop påvisningen af, hvorledes den "gode" katolske antisemitisme godt nok distancerede sig højlydt fra raceantisemitismen men samtidig havde afgørende betydning for miljøet på fem felter som han betegnet som Kontermodernisierung, Komplexitätsminderung, Kohärenzmaximierung, Kompensation og Konkurrenzbewältigung. Det katolske miljø så sig samtidigt konfronteret på tre fronter: staten, protestantismen og liberalismen og jøderne synes i miljøets perception at udgøre en central destruktiv kraft på enhver af disse fronter.

Vigtigt på et mere generelt, metodisk niveau er i denne sammenhæng Blaschkes skelnen mellem på den ene side den autonome og eksplicitte "bekendelses-antisemitisme", som raceideologerne og parti-antisemitterne repræsenterede, og på den anden side "gennemsnitstyskerens" på mange måder mere skæbnesvangre, integrerede og implicitte "konsensus-antisemitisme". Denne sidstnævnte føjede sig ind i overordnede verdensbilleder som moralprotestantismen og viste sig derved at være mere sejlivet, overbevisende og ualmindelig funktionel. "Gennemsnitstyskerne" ville opfatte det som en fornærmelse at blive betegnet som antisemitter, for hvem de kun havde foragt tilovers for, samtidigt med at de fremstillede deres antijødiske ressentiment som et legitimt forsvar mod "jødedommen". ${ }^{38}$

Det er en overvejelse værd, om Blaschkes analyse af denne ambi- 
valente konstellation - der både indebærer en distancering fra antisemitismen på den ene side og en fastholden ved et jødehad, der er indskrevet i miljøets kulturelle fundament og overføres $\mathrm{i}$ social praksis - ikke også burde have metodiske implikationer for en ny undersøgelse af synet på jøder i det danske samfund: Måske skulle tilsvarende problemstillinger formuleres med henblik på relevante danske miljøer. Foreløbige forskningsresultater peger på, at man i forskellige kontekster hyppigt møder den samme afstandtagen fra antisemitismen, men at denne samtidig på bedste antisemitisk vis kobles til et principielt krav om, at jødernes indflydelse i samfund og kultur burde reduceres. ${ }^{39}$ Begrundelsen for, at dette krav kun fremføres med en vis tilbageholdenhed, bliver ofte eksplicit sat i forbindelse med, at "problemet" ikke har samme presserende karakter i Danmark, fordi jøderne er så få og "assimilerede" her i landet.

\section{Antisemitismen i brydningsfeltet mellem kultur-ogsocialhistorie}

En række af de allerede nævnte forskere kan også tages til indtægt for et andet træk i den yngre forskningsdiskussion: pointeringen af den antisemitiske ideologis relative uafhængighed af socio-økonomiske interesser og faktorer. Et vigtigt værk, der allerede tidligt gjorde op med de forenklede teser, som det socialhistoriske paradigme potentielt implicerede, var Werner Bergmanns og Rainer Erbs "Nachtseite der Judenemanzipation" (1989). De to forskere fra Zentrum für Antisemitismusforschung ved Technische Universität Berlin sandsynliggjorde ud fra et righoldigt materiale, at den moderne antisemitisme i slutningen af r800-tallet kunne trække på et bredt arsenal af negative jødebilleder, stereotyper og legender, som allerede fra omkring I800 havde ledsaget emancipationsprocessen og løbende blev aktualiseret i kampen mod jødernes inklusion i samfundet. Således blev der sat spørgsmålstegn ved, om det primært var det borgerlige samfunds opkomst og økonomiske krisekonjunkturer, der determinerede overgangen fra traditionelt jødehad over emancipationens sejr til raceantisemitismens gennembrud.

Ud over ovennævnte pionerværk bør der i denne sammenhæng også henvises til Albert Lichtblaus sammenligning af antisemitismen i Berlin og Wien (I994). Dette studies detaljerede analyser kan ikke kun læses som en velkommen advarsel mod forhastede generalise- 
ringer; de skaber også grundlag for væsentlige differentieringer ved at skelne mellem forskellige erhvervsgrupper: Lichtblau kommer f. eks. frem til, at skræddernes erhvervsorganisationer, der stod i konkrete økonomiske konflikter med jødisk-dominerede handelsgrene, gav udtryk for en mere traditionel antijudaisme. Handelsassistenter og kontorister stod derimod ikke i nogen direkte socio-økonomisk konflikt med jøder og propaganderede en mere racistisk, postemancipatorisk antisemitisme.

Et tvivlsomt eksempel på denne tendens til at sætte spørgsmålstegn ved de social-økonomiske begrundelser for antisemitismens konjunkturer er Paul Lawrence Roses konstruktion af en voldelig, "revolutionær" antisemitisme, der angiveligt skulle være dybt rodfæstet specielt i tysk kultur og mentalitet. Denne konstruktion er en ren idéhistorisk projektion og mener at kunne undvære enhver form for socialhistorisk kontekstualisering. Selvom man ikke kan bebrejde Rose, hvem der benytter sig af hans forskning, er det dog ikke tilfældigt, at dette værk netop er en af de få monografier om antisemitisme, som Daniel J. Goldhagen trak på for at konstruere Holocaust som et nationalt tysk projekt, båret frem af en enestående og specifik eliminatorisk antisemitisme. Goldhagen har modsætningsvis ment at kunne undvære en inddragelse af den eksisterende forskning indenfor dette felt. ${ }^{40}$

Bortset fra slige betænkelige tiltag tyder meget dog på; at det ikke mere i samme grad bliver accepteret som tilstrækkeligt at afsløre antisemitiske tankestrukturer som "falsk bevidsthed" og identificere de bagvedliggende økonomiske interesser. Forskningen har nu i en årrække båret præg af den indsigt, at det er nødvendigt at tage mentale, kulturelle og ideologiske forhold alvorlige, som selvstændige historiske faktorer i deres egne ret. I denne sammenhæng er det værd at bemærke, at både Rohrbacher og Harris i deres her diskuterede værker understreger det ideologiske elements betydning ud fra en socialhistorisk synsvinkel - altså langtfra repræsenterer en traditionel idéhistorisk tilgang, der isoleret fokuserer på kulturelle og ideologiske produkter, som det er tilfældet hos for eksempel Wolfgang Altgeld (1992).

Et første forsøg på at skabe grundlaget for en moderne socialhistorisk analyse af antisemitismen implicerer således, at the linguistic turn 
tages alvorligt som udfordring på et historieteoretisk plan, uden at der gives afkald på en samfundshistorisk kontekstualisering. The linguistic turn er som begreb selvsagt kun udtryk for det fortvivlede forsøg på at samle "kulturalismens" nye metodiske og teoretiske uoverskuelighed under en mindste fællesnævner. Denne kan måske defineres som erkendelsen af, at sprog og symboler har en betydning i sig selv - som faktorer, der er med til at konstituere "realitet". Gøres der samtidig et forsøg på at fastholde den socialhistoriske arv, implicerer dette på et metodisk plan måske først og fremmest, at man holder fast ved en skelnen mellem tale og handling. Derimod ville en mere radikal position antageligt netop sætte "sproglig handlen" på lige fod med anden form for handling og pointere, at man netop ikke kan gøre udsagn om den historiske handling som sådan, fordi den altid bliver formidlet af (kildernes) tekst - hvorved man igen er på sprogplanet.

Med hensyn til denne problemstilling er det værd at lægge mærke til den selektive reception, som Shulamit Volkovs teser kom ud for især i Tyskland: I begyndelsen blev der primært fokuseret på hendes indholdsmæssige argument, at holdningen til "jødespørgsmålet" skal forstås som en indikator for en specifik gruppes kulturelle identitet og markerer skellet mellem en emancipationsvenlig og en antiemancipatorisk lejr. Derimod blev hendes metodiske argumentationslinje oftest overset: at antisemitismen ikke skulle forstås som en direkte reaktion på realiteter, men at historikeren bliver nødt til at tage udgangspunkt i jødehadets kulturelt imaginære grundlag, der som enhver fortolkning af virkeligheden er et selvstændigt, kreativt produkt. Isteder fik ikke mindst Till van Rahden rollen som foregangsmand ved at introducere denne dimension i forskningen og gøre den til udgangspunkt for sit eget arbejde (van Rahden 2000).

Van Rahden revitaliserer således ældre idéhistoriske perspektiver, der ikke mindst går tilbage til historikere som George Mosse (1964) og Uriel Tal (1974). Han viger samtidig ikke tilbage for kulturalismens appel om at tage den ideologiske og kulturelle dimensions betydning og dynamik alvorligt. På netop dette punkt tydeliggør hans tilgang, at en skelnen mellem ideologi og tale på den ene, og handling, politik eller praksis på den anden side stadig er analytisk uundværlig. Rahdens forskning illustrerer utvetydigt, hvordan kul- 
turelle, politiske og institutionelle forudsætninger sætter rammerne for, hvilke antisemitiske holdninger der får konkrete konsekvenser. Det er altså ikke primært afgørende, hvor vigtig antisemitismen er for antisemitterne, eller om der er en speciel form for tysk antisemitisme. Antisemitiske idéer bliver ikke til praksis "af sig selv", forudsætningerne for at føre dem ud i praksis må inddrages i undersøgelsen.

Van Rahden viser i denne sammenhæng, hvorledes skiftet $\mathrm{i}$ indvandrings- og statsborgerskabspolitikken i Breslau blev muliggjort, ved at den antisemitiske bevægelse skabte en stemning i den offentlige opinion, der igen skabte grundlag for en reorientering i statens politik. Derimod forblev skolepolitikken i Breslau liberal, fordi den kommunalpolitiske "upolitiske" etik forbød skarp agitation og konflikt på dette område. Det var altså de etablerede normer for, hvad man måtte og kunne sige; der havde afgørende indflydelse på antisemitismens chance for at blive politisk relevant. I Breslau var antisemitismen en kulturel kode men ikke den herskende sociale norm. Den signaliserede tilhørsforholdet til et - traditionelt eller populistisk - konservativt miljø men forblev dog samtidig minoritetsposition. Meget taler for, at denne tilgang og dens muligheder for at skelne mellem forskellige funkrioner og sammenhænge for antisemitismen med stor gevinst vil kunne anvendes i en analyse af antisemitismens rolle i det danske samfund.

En yngre historikergeneration har således kunnet vise, at det hverken er nok at spørge efter den antisemitiske ideologis udbredelse og manifestationer eller at undersøge sociale årsager til antisemitismen: Meget tyder på, at den fremtidige forskning snarere vil integrere to relaterede felter. På den ene side vil der sandsynligvis trækkes mere på diskurs- og idéhistoriske, kulturantropologiske og psykohistoriske metoder for at undersøge antisemitismens genese. ${ }^{41}$ Men en bredere samfundshistorisk analyse af antisemitismen vil tillige undersøge, om, hvorledes, og i hvilken grad det lykkedes for den antisemitiske bevægelse at omsætte dens ideologiske krav til politisk praksis og handling. For at sige det med van Rahdens ord: "wichtig ist [...] die Untersuchung des vielschichtigen und kontingenten Übersetzungsprozesses, in dem antisemitische Ideologie in politische Praxis umschlägt." (van Rahden I998, 242). Meget taler for, at dette sidstnævnte felt også vil drage stor nytte af at integrere en "Alltags- 
geschichte" af antisemitismen og - $i$ endnu højere grad - at knytte denne tilgang til en tilbundsgående analyse af forholdet mellem jøder og ikke-jøder.

Den stærkere fremhævelse af kontinuitetselementet har selvsagt også haft konsekvenser for diskussionen om antisemitismens betydning for mordet på Europas jøder. De senere års forskning har bidraget til en væsentlig mere konkret forståelse af selve forbrydelsen, især ved at undersøge en række af forskellige - og ofte oversete - grupper af gerningsmænd med hensyn til deres baggrund, motiver og specifikke bidrag til massemordet. ${ }^{42}$ Denne udvikling, der tog sin begyndelse først i I990erne og ikke mindst blev hjulpet på vej af de østeuropæiske arkivers $\varnothing$ gede tilgængelighed, kan især tilskrives en yngre generation af tyske NS-forskere som Dieter Pohl, Thomas Sandkühler eller Christian Gerlach, og har frataget debatten mellem intentionalister og strukturalister henholdsvis funktionalister dens betydning som afgørende konfliktlinie i Holocaustforskningen.

En milepæl i dette felts nyorientering var derudover Ulrich Herberts biografi om Werner Best, der med sammenfletningen af detaljeret biografisk narration og bred historisk kontekstanalyse allerede idag er et standardværk. P̊a den baggrund kan det kun undre, hvem eller hvad der har forhindret en dansk oversættelse af dette værk, der jo også for besættelseshistoriografien er af overvældende betydning. ${ }^{43}$ Herbert, der til og med er en vigtig mentor for store dele af den nye Täterforschung, kunne i denne imponerende undersøgelse netop med konkret udgangspunkt i en af hovedorganisatorerne af NS-terroren påvise, at der ikke eksisterede nogen principiel modsætning mellem rationel, kold beregning og ideologisk motiveret iver: Bests Antisemitismus der Vernunft passer ikke ind i de konventionelle argumentationskategorier, historiografien endnu i x980erne opererede med. ${ }^{44}$

Det skal dog i denne sammenhæng ikke forklejnes, at også Goldhagen, hvis man ser bort fra hans bogs problematiske slutninger på det metodiske plan, er et udtryk for denne nytænkning i Holocaustforskningen, der fokuserer på gerningsmændenes mentalitet for at forklare det såkaldte missing link mellem "normalitet" og massemord, mellem beslutningstagere og de egentlige udøvere, som har været så karakteristisk for den ældre forskning. Både Ulrich Herbert, 
Christopher Browning og Daniel J. Goldhagen anlagde et individualiserende perspektiv og bidrog dermed, til trods for deres meget forskellige resultater, til at overvinde en forskning, der var kørt fast $i$ konflikten mellem en forskningstradition, der anså nazismens samfundsmæssige strukturer i sig selv som radikaliserende, og en anden, der tolkede Holocaust som nogle enkelte ledende skikkelsers store målrettede, ideologiske projekt. Samtidig har Goldhagen på linje med de førstnævnte dog mere eller mindre ufrivilligt, været med til at fremprovokere ny forskning i sammenhængen mellem antisemitismen og Shoa. ${ }^{45}$

Ideologiens rolle er påny til debat. Men denne debat favner markant forskellige opfattelser af, hvordan ideologiens rolle defineres - fra deterministiske linearitetsforestillinger og Sonderwegs-tesens ulyksalige renaissance hos Rose og Goldhagen til den israelske historiker Oded Heilbronner, der fremhæver den tyske antisemitismes svaghed i 1800-tallet og perioden op til I. Verdenskrig (Heilbronner 2000). Lige så lidt som Goldhagens teser om jødemordets årsager og forløb ved nærmere eftersyn har vist sig at holde stik, har hans bud på den tyske antisemitismes karakter og betydning heller ikke holdt stand over for den faglige kritik. ${ }^{46}$ Omkring år 1900 ville man næppe have forventet en massiv pogrom i Tyskland - der havde vundet symbolsk status med hensyn til jødernes succes i det moderne samfund - men snarere i Frankrig og især Rusland. Tilmed har Olaf Blaschke systematisk dekonstrueret forestillingen om en "eliminatorisk antisemitisme" som en tautologisk fejlslutning og ubrugelig analysekategori. ${ }^{47}$

Anskuet som helhed, synes ideologiens og kontinuitetens rehabilitering at have været en frugtbar og overbevisende nyorientering inden for forskningen, for så vidt den ikke har ignoreret de samtidige kontinuitetsbrud og det kontingente element i udviklingen fra Fichte til Himmler. Hvor den derimod implicerede ny determinisme, linearitet og simplificerende kausalitetskonstruktioner, har forskningen vist sig at ende i nye blindgyder.

\section{Forboldet mellem nation, nationalisme og antisemitisme}

Et sidste træk i den aktuelle forskning, der skal diskuteres her, er debatten om forholdet mellem nationsdannelse og jødehad. Ofte inspireret af den nyere nationalismeforskning har et stigende antal 
historikere taget afstand fra at forstå nationen som nærmest underforstået referenceramme for antisemitismen. Dette er sket på tre niveauer:

For det første er sammenhængen mellem nationsdannelse og jødernes eksklusion fra eller inklusion i denne nation selv blevet gjort til genstand for historiske undersøgelser. Det er kun få år siden, at Till van Rahden beklagede netop denne lakune (van Rahden 1996). Men siden da er der sket en hel del i forskningen. Ud fra meget forskellige metodiske forudsætninger har - for at nævne nogle fremtrædende eksempler - både Dagmar Herzog (1996, for hertugdømmet Baden) og David Feldman (1994, for Englands vedkommende) undersøgt antisemitismen som den nationalt orienterede, liberale bevægelses akilleshæl: Begge har kunnet demonstrere, at selv liberale demokrater arbejdede for at etablere et homogent kristent samfind, der ikke levnede meget rum til multikulturelle strukturer eller til den vedvarende eksistens af kollektive gruppeidentiteter, der blev opfattet eller forstod sig selv som afvigende fra den kulturelle, religiøse eller etniske norm. Titlen på en vigtig antologi, der opsamler de sidste års forskningsbidrag på dette felt, Die Konstruktion der Nation gegen die Juden, sætter i øvrigt kort og præcist ord på, hvad dette perspektiv handler om (Alter 1999). Det mest aktuelle bud på en undersøgelse af forholdet mellem nationalisme og antisemitisme er Klaus Holz' imponerende "habilitations"-afhandling ( $\mathrm{Holz} 200 \mathrm{I}$ ), der ud fra en rekonstruktionslogisk metode finder en ny og plausibel tilgang til antisemitismens semantik og dens politiske og sociale implikationer fra Treitschke over Stoecker, Drumont og Hitler til antisemitismen efter 1945, hvor der fokuseres på Polen og Østrig som eksempler.

En anden dimension $i$ denne problematisering af nationen som implicit referenceramme kan ses i den voksende interesse for det lokale og regionale plan som udgangspunkt for historiske undersøgelser: ${ }^{48}$ Denne forskydning har i væsentlig grad bidraget til et mere konkret, nuanceret og detaljeret billede af antisemitismen. Derudover har lokalhistoriske studier vist sig at byde på gode muligheder for at flette en analyse af antisemitismens semantik og praksis sammen med en undersøgelse af de skiftende relationer mellem jøder og ikkejøder. På dette punkt bliver den (modificerede) socialhistoriske til- 
gangsvinkels vedvarende betydning tydelig, idet sådanne regional- og lokalstudier ofte funderes på de "konkrete" samfundsmæssige relationer, for da med dette udgangspunkt at foretage undersøgelser af mønstre og forskydninger af mentale og kulturelle forhold. Endnu vigtigere er måske, at der på denne måde slås bro mellem antisemitismeforskning og jødisk historie: Netop med en by- eller regionalhistorisk tilgang åbnes op for en kombination af undersøgelsen af jødiske livsformer med analysen af forholdene mellem jøder og ikke-jøder.

Et af de mest radikale aktuelle bud på antisemitismeforskningens "regionalisering" er antagelig Oded Heilbronner. Han kritiserer netop det klassiske socialhistoriske paradigme, der var fikseret på nationalstaten som fortolkningstamme, for ikke at være i stand til at forklare, hvorfor antisemitismen ikke var "moderniseringstabernes" yndede protestform på landsplan men kun i specifikke regioner. Her munder opgøret med nationen som den underforståede referenceramme nærmest ud i en Anti-Sonderwegs-tese: "The absence of any dominant cultural hegemony, any single political culture in Germany largely explains the limited spread of antisemitism." (Heilbronner 2000, 564)

Som et tredje udtryk for dette opgør med nationen som implicit referenceramme kan man sluttelig tilsvarende se de spæde tiltag til en (primær europæisk orienteret) komparativ antisemitismeforskning. ${ }^{49}$ Men denne udvikling er hidtil blevet bremset af to faktorer: den etablerede historieforsknings alment tøvende holdning over for komparativ historieskrivning, som var at finde i de fleste nationale videnskabskulturer i det mindste indtil for få år siden, og problemet, at forskningen $\mathrm{i}$ høj grad primært har været optaget af den tyske antisemitismes historie. En første forudsætning for komparative studier var således, at man også begyndte at tage bestik af antisemitismen i andre kulturer end den tyske. ${ }^{50}$

Med sådanne studier var der et grundlag for at sammenligne antisemitismen henover nationale og kulturelle grænser. ${ }^{51}$ Men selvom der er fremkommet indledende interessante bud på en sådan nyere komparativ antisemitismeforskning, er der god grund til at være på vagt: Tony Kushner, der er en af de mest inspirerende pionerer inden for udforskningen af det liberale engelske samfunds antisemitisme, har således formuleret en væsentlig advarsel imod komparativ forsk- 
ning. Den engelske historiker peger især på den fare for forvrængning og bagatellisering, der ofte er forbundet enten med fremhævelsen af ens egen nations helt exceptionelle udvikling eller konstruktionen af et "positivt" eksempel som modsætning til "de andres" antisemitisme - oftest Tysklands antijødiske traditioner og nationalsocialismens folkemord på de europæiske jøder:

Comparing antisemitisms ... have often been exercises in polarized myth-making. The Holocaust has made the construction of national typologies all the more easy and apparently convincing. [Ofte har det komparative element ikke bestået i mere end] the creation of league tables in which the liberal democratic world occupies the lower reaches in order to show off all the more effectively the real villains. Comparisons between Britain and Germany are perhaps the most difficult to deconstruct because antisemitism, and racism more generally, has been strongly established in British culture as fundamentally un-English, meaning, at least since 1945, not German. (Kushner 1999, 94)

\section{KONKLUSION: IMPLIKATIONER FOR DANSK}

\section{ANTISEMITISMEFORSKNING}

Den komparative fælde er et tilsvarende problem for den historiske debat om antisemitismen i Danmark. Forestillinger om det "udanske" ved racisme og antisemitisme - $i$ et decideret modsætningsforhold ikke mindst til tysk mentalitet - har ofte kvalt forskningens kritiske spørgsmål, før man overhovedet tog fat på en egentlig analyse. ${ }^{52}$ Men på den anden side kan der være god grund til at vælge at se det problem, som Kushner skildrer så rammende, som en produktiv udfordring: Kendsgerningen, at Dansk Center for Holocaust- og Folkemordsstudier i marts 2001 organiserede den første konference om emnet "Antisemitisme i Danmark?" signalerer, at emnet er på vej ind i dansk historiografi - selvom man åbenbart ikke mente at kunne undvære at sætte et (i det mindste retorisk) spørgsmålstegn ved titlen. Den manglende forskning og de skildrede immunitetslegender $i$ den konventionelle nationale fortælling betyder rigtig nok, at man 
forskningsmæssigt i mange henseender står på bar bund. Men på den anden side kan denne situation være en mulighed for at undgå nogle af antisemitismeforskningens blindgyder ved at trække på nyere tilgange fra det bredt definerede cultural studies-felt. Ved at undersøge hvorledes identiter er blevet konstruerede i relation til "jøden" som den "anden", kan man tilmed forvente at nå frem til nye perspektiver på mere almene problemer i dansk historie.

Udfordringen vil så åbenlyst bestå i ikke at forklejne denne antisemitisme ved at holde den op imod Auschwitz. Der skal findes en produktiv balance mellem bagatellisering og dramatisering, mellem et opgør med forestillingen om den danske folkelighed, der er immun over for slige ubehageligheder og en metodisk funderet historisk analyse uden behov for journalistisk sensationalisme. Der er intet behov for, med en anklagende, skinger røst at begynde en skandalejagt i den danske histories mindre hyggelige sider.

Jeg vil sammenfatte min argumentation ved at henvise til seks aspekter, som en fremtidig dansk historisk forskning, der tager emnet antisemitisme op, vil kunne drage nytte af.

I) At skrive Danish history from the margins implicerer i denne sammenhæng først og fremmest at undersøge antisemitismens betydning $\mathrm{i}$ en forholdsvis tidlig udpræget liberal kultur. ${ }^{53}$ Samfundets demokratisering og nationalisering var processer, der i høj grad var forbundet med spørgsmalet om, hvem der skulle høre med til "the circle of the We" (David Hollinger). En spirende dansk antisemitismeforskning burde således blandt andet analysere de diskurser, kulturelle mønstre og sociale strukturer, der skaber mulighederne for at integrere nationen via jøders - imaginerede eller reelle - eksklusion. Hvad var årsagerne til, at der opstod en dansk-kristen selvforståelse, der implicerede et betydeligt akkulturationspres og kun levnede plads til "andre", såfremt disse ikke gjorde krav på en særegen kollektiv kulturel identitet men var villige til at bøje sig for homogenitetens diktat? Det er vist ikke nødvendigt at gøre de politisk-aktuelle dimensioner i denne problemstilling eksplicitte.

2) En anden udfordring består $i$ at undgå en isoleret analyse af antisemitismen, men istedet at undersøge fænomenet som et integreret delelement $\mathrm{i}$ bredere kulturelle orienteringsmønstre og social praksis - som mørtelen i et specifikt miljø eller subkultur; flettet sam- 
men med nationalisme, antimarxisme og andre orienteringer. En sådan forskning ville ikke nøjes med at destillere "antijødiske verdensbilleder" men gøre sig den umage også at undersøge de ideologiske systemer og kulturelle miljøer, de er del af - og inden for hvilke de udfolder deres virkning, semantisk, diskursivt og praktisk. Et andet meget afgørende analytisk skridt ville dernæst være at skelne mellem antisemitiske stereotyper og antisemitiske løsningsmodeller: ikke enhver artikulering af en jødefjendtlig fordom, selv i den mere eksplicitte form, indebærer samtidig et bud på en løsning af "problemet" faktisk peger undersøgelser af tyske antisemitiske skrifter på, at sidstnævnte handlingsorienterede antisemitisme er undtagelsen. Når klerikale kredse angreb den "jødiske liberalisme", indebar denne stereotyp jo ikke en konkret handlingsoption, der var rettet mod jøder, og problemet, der stod i centrum, var ikke så meget "jøde-", men snarere "liberalismeproblemet". Som både Niewyk og Blaschke har pointeret, er det yderst relevant for en historisk forståelse af antisemitismen at skelne mellem - for eksempel tre - forskellige kategorier af løsningsforslag: Én løsningsmodel er inklusionen, der kobles med rigide assimilationskrav. De negative karaktertræk, man tillagde jøderne - om det så var overtro, partikularisme, sekularisme eller materialisme - kunne overvindes ved radikal tilpasning. Her var det paradigmatiske kodeord amalgamering. Antageligt implicerede et perspektiv, der gik ud på sammensmeltning, en potentiel afvisning af en selvstændig jødisk kulturs eksistensberettigelse og af en distinktiv kollektiv identitet som jødisk samfund - dog ikke en afvisning af jøden som individ. En anden kategori af løsningsoptioner var eksklusionen og segregationen, vel det mest udbredte program hos "bekendelses-antisemitter". Mulighederne for handling kunne række fra retslig diskrimination til social apartheid. Tredje og sidste kategori kan defineres som den vifte af muligheder, der spænder fra udvisning til (vag) elimination og (konkret) ekstermination. Danske forskeres diskussion af emnet antisemitisme har ofte lidt meget under en mangel af sådanne distinktioner. Dertil kommer, at man alt for længe har konkluderet, at der egentligt ikke var noget relevant at undersøge i det danske jødehads historie, fordi den anden og især den tredje kategori af løsningsmodeller ikke var særlig synlige i den danske kultur.

3) En systematisk forskning i dansk jødehad og antisemitisme 
burde ikke tage diskontinuiteten som udgangspunkt på tilsvarende aksiomatisk vis, som en del af historiografien om tysk antisemitisme har gjort det med kontinuiteten. Der må være plads til både at se det kontingente element i udviklingen og samtidig spørge efter traditionslinjer $\mathrm{i}$ dansk jødehad. Tidligere forsøg på at beskrive antisemitisme i Danmark har defineret dens udtryksformer i razoerne og I93oerne som et begrænset tidsfænomen, og det analytiske perspektiv stopper dér. ${ }^{54}$ Imidlertid burde man måske netop begynde med at rejse spørgsmål på dette punkt: Hvad er forudsætningerne for, at man reagerede på "østjøder" på en sådan måde i Danmark? Hvorfor fungerer argumentet, der associerer jøder med bedrageri eller destruktiv umoral, også - eller endda - i Danmark? Kun ved systematisk at undersøge kontinuiteter og diskontinuiteter i forholdet mellem jøder og ikke-jøder i Danmark kan en størrelse som dansk antisemitisme blive analyseret mere fyldestgørende end det er sket hidtil.

4) Derudover vil det synes lovende at kombinere det socialhistoriske paradigmes analysemetoder med kulturhistoriske problemstillinger for at undersøge den dobbelthed, der ligger i jødehadets betydning for det danske samfund: Meget taler for den hypotese, at antijødiske stereotyper var et vigtigt element i en række af danske subkulturer og miljøer, men det antisemitisk formulerede "jødespørgsmål" blev kun i meget ringe grad besvaret med egentlig "eliminatoriske" løsningsmodeller. Målet må være at kortlægge de sociale strukturer og kulturelle orienteringsmønstre, der medvirkede til denne konstellation.

5) Under forudsætning af, at man opgiver forenklede dikotomier mellem de tolerant-liberale danske og de illiberale tyske traditionslinjer, kan også en komparativ historieforskning med fokus på antisemitisme udfolde et frugtbart, kritisk potentiale ved at gå den liberale traditions ambivalens efter i sømmene - især med hensyn til spændingsforholdet mellem ligestilling og forskellighed, mellem universalisme og partikularisme.

6) Et sådant metodisk grundlag for en ny forskningsagenda ville også i højeste grad være kompatibel med dansk-jødisk historieforskning, hvis potentialer for nye perspektiver på dansk og europæisk historie ligeledes langtfra er blevet udnyttet udtømmende. Det betyder langtfra at gå på kompromis med princippet om, at antisemi- 
tisme grundlæggende er det ikke-jødiske samfunds problem. Snarere kan disse to dimensioner af en forskning i relationer mellem jødiske og ikke-jødiske danskere være til gensidig berigelse. Begge felter har brug for nytænkning. Det gælder ikke kun med hensyn til, at jøder både må analyseres som handlende subjekter $\mathrm{i}$ historien og som et objekt for flertalssamfundets projektioner og handlinger. Der er også behov for at anerkende, at det ikke giver mening at tale om to homogene enheder, det danske ikke-jødiske versus det dansk-jødiske samfund. Snarere må man analysere både flertallets og mindretallets kultur og identitetskonstruktioner som sammensatte, pluralistiske og flydende størrelser - og det er her, at antisemitisme og jødisk historie som felter for historisk forskning potentielt er komplementære.

\section{Noter}

1. Jfr. som introduktion med litteraturhenvisninger: Wagner $2001 \mathrm{~b}$. Artiklen berører nogle aspekter af mit ph.d.-projekt, der undersøger jødernes emanicipation og akkulturation i Danmark 1780-1850, set i et komparativt europæisk perspektiv.

En vigtig undtagelse er Martin Schwartz Laustens undersøgelser, der strækker sig helt fra middelalderen op til oplysningstiden og primært belyser biskoppers og præsters syn på jøder i et kirkehistorisk perspektiv. Jfr. Schwarzz Lausten 1992 og 2000.

2. Jfr. Helen Feins ikke uproblematiske forsøg på en sådan "kvantificering": Fein 1979, især kap. 2: "The Calculus of Genocide".

3. Her kan der istedet henvises til Reinhard Rürups og Thomas Nipperdeys stadig autoritative artikel om emnet (Rürup/Nipperdey 1987). En antologi, der samler nogle af de vigtigste - både ældre og yngre - bidrag til den tyske antisemitismes historie er Benz/Bergmann 1997.

4. Et karakteristisk eksempel på sidstnævnte manøvre er Hammerstein 1995.

5. Massing 1949; Arendt 1951; Poliakov, 1955-77, og vigtigst: Pulzer 1964 - men jfr. også Studies in prejudice-projektet, initieret af eksilerede repræsentanter for Frankfurterskolen samt amerikanske forskere, der mundede ud i tesekomplekset omkring "The Authoritarian Personality", som et enestånde eksempel på interdisciplinaritet $i$ antisemitismeforskningen. Den socialvidenskabelige og psykologiske forskning må af pladsgrunde negligeres her; der henvises til Bergmann 1988.

6. Jfr. iser Rürup 1987, og samme forfatters artikder. Rürup 1976, 1986 og 1991.

7. Andre berydningsfulde bidrag var Greive 1983 og Jochmann x988. Et vigtigt og meget nyttigt, sammenfattende opsamlingsbind for denne gren af forskningen er Berding 1988. DDR-historiografien må ligeledes forbigås her. Den evnede kun $i$ begrenset omfang og meget sent at befri sig fra den marxis- 
tiske ideologis spændetrøje, som den kom til udtryk i den Kommunistiske Internationales antisemitismedefinition og antizionismen.

8. Især siden tresserne vandt en syn på årsagerne til nazismen frem, der tolkede den som en følge af, at Tysklands overgang til et moderne samfund havde været grundlæggende forskellig fra de andre europæiske samfunds udvikling. Den konfessionelle modsætning mellem protestantisme og katolicisme, rigets opsplittelse i et utal af større eller mindre stater, borgerskabets svækkede stilling, manglen på en borgerlig-demokratisk revolution samt den forsinkede industrialisering blev set som forstyrrende elementer i denne moderniseringsproces. Disse faktorer havde muliggjort etableringen af et autoritært tysk kejserrige under Bismarck, der blev domineret af semifeudale, militaristiske, antisemitiske og antidemokratiske eliter og på denne måde banede vejen for Hitler. I løbet af halvfemserne er forskningen i stadig større grad gået bort fra denne tolkning, ikke mindst fordi den implicit konstruerede en formentlig homogen engelsk-fransk vej ind i det moderne samfund som den ideelle norm.

9. Aly og Heim I99r; Aly 1995; Schmuhl 1992; Friedländer I995.

I0. Baron I928.

II. Birnbaum og Katznelson (1995) giver et godt indtryk af denne udvikling; jfr. generelt Till van Rahdens meget inspirerende essay om antisemitismeforskningen (van Rahden 1996).

12. Jfr. Diner 1988, især Dan Diners forord, s. 7-I3

13. I denne sammenhæng kan der peges på to nye publikationer: Benz (200I) er en antologi, der også omfatter nogle afsæt til overvejelser af mere principiel, metodisk karakter, mens Bergmann (2002) nok er den nyeste - og måske endda den første - systematiske introduktion til emnet antisemitisme som genstand for historisk forskning.

14. F. eks. Sterling 1950, samt 1969; jfr. også den indflydelsesrige undersøgelse af Hans Rosenberg ( 1967 ), der fortolker den moderne antisemitisme som et produkt af Gründerkrise, den store depression efter 1875 .

I5. Dirk Blasius krævede således meget karakteristisk i en forskningsoversigt fra 1978, "die 'Judenfrage' mit dem Entwicklungsgang der modernen, kapitalistisch verfaßten Gesellschaft zu korrelieren” (Blasius 1978, I7).

I6. Jfr. som et eksempel af nyere dato på dette problem den nyere tyske socialhistorieskrivnings nestor Hans-Ulrich Wehlers behandling af det "kulturelle" i hans ellers imponerende gennemstrukturerede og voluminøse firebindsværk, Deutsche Gesellschaftsgeschichte, 1987.

I7. Jfr. især hans "Judenemanzipation und bürgerliche Gesellschaft in Deutschland", i: Rürup $x_{987}, 13-45$.

18. Disse forhold, som er en oplagt mulighed for at at anlægge en ny synsvinkel på det ikke-jødiske samfunds udvikling, er endnu ikke blevet undersøgt for Danmark; de udgør en central dimension af mit nævnte ph.d. projekt.

I9. Christian Wilhelm von Dohm, Über die bürgerlicbe Verbesserung der Juden, Berlin/Stettin I78r.

20. "Nach I830 trat die liberale Forderung nach einer Reformation des Judentums in den Hintergrund, und auch die 'christliche' Politik einzelner Staaten in den vierziger Jahren führte nicht mehr zu dieser Forderung zurück. Es 
begann eine neue Phase der Diskussion, in der die Gleichstellung der Juden nun nicht mehr allein als Mittel zum Zweck ihrer 'bürgerlichen Verbesserung' oder 'Civilisation' gefordert wurde. Die Judenemanzipation wurde von jetzt an zu einer Frage des Prinzips - wenn nicht in der Realiäat, so doch in den Forderungen. Der Liberalismus begann wenigstens in einzelnen Vertretern auf der Höhe seiner Prinzipien zu argumentieren." (Rürup 1987, 30).

2x. Rose 1990; Goldhagen 1996, og Weiss 1996.

22. Harris 1994; Rohrbacher 1993 og Rürup 1998.

23. Jfr. igen Rohrbacher 1993; men også Hoffmann 1994. Walter (1999) er ligeledes et vigtigt bidrag, især i kraft af at forfatteren kobler antisemitismeforskningen til den nyere voldsforkkning; men også dette første store værk om tysk antisemitisme i mellemkrigstiden har langt fra formået at udfylde de mange lakuner, som forskningen i antisemismens former og betydning under Weimarrepublikken stadig er præget af. Heilbronner (2000) gør sig dog - ud fra en regionalhistorisk vinkel - nogle stimulerende overvejelser om antisemitismens geografiske spredning og manglende kontinuitet fra Kejserriget ril det Tredje Rige. Vigtige nye studier vil blive publiceret i Bergmann, Hoffmann og Smith 2002.

24. Hos Altgeld (1992) og Hammerstein (1995) foranlediger sammenligningen med antikatolicismen dog en dybt problematisk bagatellisering af antisemitismen. Et yderligere interessant eksempel på et forsøg på en komparativ tilgangsvinkel er Wippermann 1997.

25. Allerede Volkov, hvis forskning vil blive diskuteret nedenfor, henviste til parallellerne og sammenhængen mellem antifeminisme og antisemitisme; jfr. derudover von Braun (I990) og Dick (1993).

26. Denne kønsorienterede forskning, som ikke mindst Mona Körte har bidraget til, har blandt andet peget på en vasentlig kønsbestemt forskel i konstruktionen af jødebilleder: Skildringer af den jødiske kvinde udrrykker sig ofte $i$ en ambivalens gennem forestillingen om "den smukke jødepige" (som potentiel konvertit!) og den faretruende syndige, seksuelt aggressive og hæmningsløse kvinde. Kønsspecifikke konstruktioner af mandlige jøder er derimod i reglen entydigt negative. Et imponerende overbliksværk af nyere dato, der undersøger den litterære diskurs over en moderne jødisk identitet og over jødernes placering i det tyske hhv. østrigske samfund, er Robertson (1999).

27. Mht. universiteterne kan igen henvises til Hammerstein (I995), men vigtigst er nok Kampe 1988, samt Pickus 1999; også Christhard Hoffmann har beskæftiget sig indgående med antisemitismens teori og praksis i det såkaldte "dannelsesborgerskab" - Bildungsbürrgertum - og blandt de lærde: jfr. dennes afhandling (Hoffmann 1988), samt artiklen om den såkaldte "Berliner Antisemitismusstreit" 1879-8I (Hoffmann I995). Angående juristerne kan henvises til Barbara Strenges dissertationsafhandling (Strenge I996), samt Heinrichs (1993). Iøvrigt vil et metodisk innovativt ph.d.-projekt ved Technische Universität Berlin blive afsluttet i dette år: Uffa Jensen, Das Verbältnis von Juden und Nichtjuden in der Bildungskultur des frühen Kaiserreichs.

28. Timm 1997; jfr. også Bischof og Neidhard (2000), som gør sig umage for at tage et længe forsømt og til dels tabuiseret emne op, men er analytisk diffus. Mere brugbar er derimod den bl.a. af Micha Brumlik redigerede anto- 
logi om venstrefløjen og antisemitismen (Brumlik I99I).

29. "When I hear anyone talk of culture, I reach for my revolver." Whether or not Hermann Göring actually made this comment, its sentiments seem to have been adapted by subsequent historians. [...] The analysis of contemporary antisemitism is just one area that has suffered from a narrow, twodimensional approach." (Kushner I99I, I8).

30. Volkov 1978.

3I. Det er netop dette forhold, der gør katalogiseringsforsøg som Julius $\mathrm{H}$. Schoeps' og Joachim Schlörs (I995) problematiske, fordi de enkelte stereotyper bliver revet ud af sådanne sammenhænge; jfr. også Rohrbacher og Schmidt (I99I).

32. Katz 1983, samt 1980, 1986 og 1994. På denne baggrund har en del anmeldere set det som en beklagelig beslutning, at Oxford University Press så sent som 1999 har bedt en historiker, der faktisk fører denne efterhånden falmende historietradition videre, om at skrive det bind til den yderst velansete række Oxford History of Modern Europe, der behandler de europæiske jøders historie. Til trods for små 1000 siders tekst præsenteres læseren endda for en ret ensidig og forenklet version af denne zionistiske historiografiske tradition, og værket tager ikke højde for den nyere forskning i det omfang, man ville kunne forvente af et potentielt standardværk (Vital 1999).

33. Yahil $1969,390-392$ et passim.

34. Jfr. antologien of Kurt Nowak og Gérard Raulet (I994), især Rita Thalmanns bidrag om kulturprotestantismen s. 147-I66, der ligger tæt op af Barbara Suchys autoritative undersøgelse om Abwehrverein (1985).

35. Langmuir r990a og 1990b.

36. Jfr. med en lignende problemstilling også Walz 1995.

37. Blaschke 1999; jfr. begrebsdannelsen hos Lepsius 1973.

38. Blaschke 1999, 70-ro6.

39. Jfr. Sofie L. Baks (Det Kongelige Bibliotek) ph.d.-projekt om antisemitismen i mellemkrigstidens Danmark.

40. Det er således påfaldende, hvormeget Goldhagen trækker på en af de tidligste - og ovenikøbet upublicerede - studier (Felden 1963), men derudover åbenbart ikke har kendskab til store dele af den nyere forskning, der ville have været yderst relevant for ham som grundlag for en afprøvning af sine vovede teser.

41. Derudover er der tiltag til en analyse af den litterære antisemitisme, jfr. ikke mindst Gubser 1998.

42. En meget nytrig introduktion til denne nye forskning byder antologien Nationalsozialistische Vernichtungspolitik 1939-1945. Neue Forschungen und Kontroversen, redigeret af Ulrich Herbert, Frankfurt a.M. 1998; Jfr. også Christoph Dieckmann et al. (red.), „Durchschnittstäter". Handeln und Motivation, Beiträge zur Geschichte des Nationalsozialismus, bd. 16, Berlin 2000, som et forsøg på at udvide denne "Täterforschung" til hidtil underrepræsenterede eller endda uudforskede persongrupper og geografiske områder.

43. Ulrich Herbert, Best. Biographische Studien über Radikalismus, Weltanschauung und Vernunft, r903-1989, Bonn 1996. Dette gælder ikke mindst på baggrund af, at Norman Finkelsteins The Holocaust Industry. Reflection on the Exploitation of Jewish Suffering, New York 2000, er blevet udgivet på dansk - til 
trods for at et flertal af anmeldere og forskere har kritiseret bogen som makværk og tilbagevist Finkelsteins konspirationsteoretiske påstande om Holocausts instrumentalisering i USA. Jfr. Steinberger 2001.

44. En opsummering af den nyere forskning og et bud på en ny syntese er Saul Friedlanders Nazi Germany and the Jews (bd I: The Years of Persecution, London 1997).

45. Jfr. ikke mindst de talrige bidrag i Bankier 2000; en meget nyttig antologi er også Frankel 1997 (jfr. iszer Geoff Eley, What are the Contexts for German Antisemitism? Some Thoughts on the Origins of Nazism, I800-1945, I0O-I32).

46. Ud over en lang række af anmeldelser, der langtfra alle levede op til en legitim forventning om en både saglig og kritisk debat, jfr. Schoeps 1996, var det isæer Dieter Pohl (1997) og Bettina Birn (1997), der som eksperter på området detaljeret demonterede Goldhagens kildeanalyse og konklusioner.

47. Jfr. Olaf Blaschkes artikel, der udkom i en antologi redigeret af Rainer Erb og Johannes Heil (r998).

48. Jfr. bl.a. af nyere dato: Kauders 1996; Friedeburg 1997, (bl.a. om forholdet mellem jøder og ikke-jøder i Hessen 1700-1900), og naturligvis van Rahden (2000), hvis titel er blevet lånt til denne artikel.

49. Endelman (1986) byder på et godt overblik over denne udvikling.

50. Jfr. f.eks. Dinnerstein 1994; Messmer 1997; Field 1983; Kushner 1989.

5I. Jfr. Hagen 1996.

52. Jfr. Wagner 200ra; som den første egentlige kildemættede og grundige undersøgelse af et specifikt, klart afgrænset miljø og dets antisemitisme skal især John T. Lauridsens artikel om DNSAP og "jødespørgsmålet" fremhæves (Lauridsen 2000).

53. Jfr. f. eks. det inspirerende oplæg til konferencen, University of Southampton organiserer til september 2002: "German History from the Margins" (www.soton.ac.uk)

54. Jfr. som eksempel på dette Lammers 1987.

\section{LITTERATURLISTE}

Alter, Peter (red.), 1999. Die Konstruktion der Nation gegen die Juden, München. Altgeld, Wolfgang, 1992. Katolizismus, Protestantismus, Judentum. Über religiös begründete Gegensätze und nationalreligiöse Ideen in der Geschichte des deutschen Nationalismus, Mainz.

Aly, Götz, 1995. Endlösung. Völkerverschiebung und der Mord an den europäischen Juden, Frankfurt a.M.

Aly, Götz, og Susanne Heim, 1991. Vordenker der Vernichtung. Auschwitz und die deutschen Pläne für eine neue europäische Ordnung, Hamburg.

Arendt, Hannah, 1951. The Origins of Totalitarianism, New York.

Bankier, David (red.), 200o. Probing the Depths of German Antisemitism. German Society and the Persecution of the Jews, I933-I94I, Jerusalem.

Baron, Salo W., 1928. "Ghetto and Emancipation. Shall we revise the traditional view?", i: Menorah Journal L4, 515-526. 
Benz, Wolfgang, 200I. Bilder vom Juden. Studien zum alltäglichen Antisemitismus, München.

Benz, Wolfgang, og Werner Bergmann (red.), 1997. Vorurteil und Völkermord. Entwicklungslinien des Antisemitismus, Freiburg.

Berding, Helmut, 1988. Moderner Antisemitismus in Deutschland, Frankfurt a.M. Bergmann, Werner, 2002. Geschichte des Antisemitismus, München.

Bergmann, Werner (red.), 1988. Error without Trial. Psychological Research on. Antisemitism, Berlin.

Bergmann, Werner, Christhard Hoffmann og Helmut W. Smith (red.), 2002. Exclusionary Violence. Antisemitic Riots in Modern German History r8IoI938, Ann Arbor.

Birn, Betrina, 1997. "Revising the Holocaust", in: Historical Joumal 40, 195-216.

Birnbaum, Pierre, og Ira Katznelson (red.), 1995. Paths of Emancipation. Jews, States and Citizenship, Princeton.

Bischof, Willi, og Irith Neidhard, 2000. Wir sind die Guten. Antisemitismus in der radikalen Linken, Münster.

Blaschke, Olaf, 1999. Katholizismus und Antisemitismus im Deutschen Kaiserreich, Göttingen (andet oplag).

Blaschke, Olaf, 1998. "Die Elimination wissenschaftlicher Urteilsfähigkeit. Goldhagens Begriff des „eliminatorischen Antisemitismus" - eine Überprüfung", i: Rainer Erb og Johannes Heil (red.), Geschichtswissenschaft und Öffentlichkeit. Der Streit um Daniel J. Goldhagen, Frankfurt a.M., $63-90$.

Blasius, Dirk, 1978. "„Judenfrage" und Gesellschaftsgeschichte", i: Neue Politische Literatur 23, 17-33.

Braun, Christina von (red.), 1990. Der ewige Judenhaß. Christlicher Antijudaismus, deutsche Judenfeindlichkeit, rassistischer Antisemitismus, Stuttgart.

Brumlik, Micha (red.), 1991. Der Antisemitismus und die Linke, Frankfurt a.M.

Clark, Christopher M., 199I. "Three Books about Antisemitism", i: Historical Journal 34, 99I-997.

Dick, Jutta (red.), 1993. Von einer Welt in die andere. Jüdinnen im Ig. und 20. Jabrbundert, Wien.

Dieckmann, Christoph et al. (red.), 2000. "Durchschnittstäter". Handeln und Motivation, Beiträge zur Geschichte des Nationalsozialismus, bd. 16.

Diner, Dan (red.), 1988. Zivilisationsbruch. Denken nach Auschwitz, Frankfurt a.M.

Dinnerstein, Leonard, 1994. A History of American Antisemitism, New York.

Dohm, Christian Wilhelm von, 178I. Über die bürgerliche Verbesserung der Juden, Berlin/Stettin.

Endelman, Todd, 1986. "Comparative Perspectives on Modern Anti-Semitism in the West", i: David Berger (ed.) History and Hate. The Dimensions of Anti-Semitism, Philadelphia, 95-Ir4.

Erb, Rainer, og Werner Bergmann, 1989. Die Nachtseite der Judenemanzipation. Der Widerstand gegen die Integration der Juden in Deutschland $1780-$ I860, Berlin. 
Fein, Helen, 1979. Accounting for Genocide: National Responses and Jewish Victimization during the Holocaust. New York.

Felden, Klemens, 1963. Die Übernabme des antisemitischen Stereotyps als soziale Norm durch die bürgerliche Gesellschaft, I875-1900, dissertation, Heidelberg.

Feldman, David, 1994. Englishmen and Jews. Social Relations and Political Culture 1840-19I4, New Haven.

Field, Geoffrey, 1983. "Antisemitism with the Boots off", i: Wiener Library Bulletin, special issue, $25-46$.

Frankel, Jonathan (red.), 1997. The Fate of the European Jews, 1939-1945. Continuity or Contingency? Studies in Contemporary Jewry XIII, New York/Oxford.

Friedeburg, Robert von, 1997. Ländliche Gesellschaft und Obrigkeit. Gemeindeprotest und politische Mobilisierung im I8. und xg. Jabrbundert, Göttingen.

Friedländer, Henry, 1995. The Origins of Nazi Genocide: From Euthanasia to the Final Solution, Chapel Hill.

Goldhagen, Daniel J., 1996. Hitler's Willing Executioners. Ordinary Germans and the Holocaust, New York.

Greive, Hermann, 1983. Geschichte des modernen Antisemitismus in Deutschland, Darmstadt.

Gubser, Martin, 1998. Literarischer Antisemitismus. Untersuchungen zu Gustav Freytag und anderen bürgerlichen Schriftstellern des Ig. Jahrbunderts, Göttingen.

Hagen, William W., 1996. "Before the "Final Solution": Toward a Comparative Analysis of Political Anti-Semitism in Interwar Germany and Poland", i: Journal of Modern History 68, 35I-381.

Hammerstein, Notker, I995. Antisemitismus und deutsche Universitäten I87xI933, Frankfurt a.M.

Harris, James F., 1994. The People Speak! Anti-Semitism and Emancipation in Nineteenth-Century Bavaria, Ann Arbor.

Heilbronner, Oded, 2000. "From Antisemitic Peripheries to Antisemitic Centers. The Place of Antisemitism in Modern German History", i: Journal of Contemporary History 35, 559-576

Heinrichs, Helmut, et al. (red.), I993. Deutsche Juristen jüidischer Herkunft, München.

Herbert, Ulrich (red.), 1998. Nationalsozialistische Vernichtungspolitik 19391945. Neue Forschungen und Kontroversen, Frankfurt a.M.

Herzog, Dagmar, 1996. Intimacy and Exclusion. Religious Politics in Pre-Revolutionary Baden, Princeton.

Hoffmann, Christhard, 1988. Juden und Judentum im Werk deutscher Althistoriker des 29 . und 20. Jabrhunderts, Leiden.

Hoffmann, Christhard, 1994. Politische Kultur und Gewalt gegen Minderheiten. Die antisemitischen Ausschreitungen in Pommern und Westpreußen x88r. Jahrbuch für Antisemitismusforschung 3, 93-I20.

Hoffmann, Christhard, 1995. "Der Berliner Antisemitismusstreit 1879/8ז", i: Geschichte in Wissenschaft und Unterricht 46, I67-178. 
Holz, Klaus, 20or. Nationaler Antisemitismus. Wissenssoziologie einer Weltanschauung, Hamburg.

Jochmann, Werner, 1988. Gesellschaftskrise und Judenfeindschaft in Deutschland $1870-1945$, Hamburg.

Kampe, Norbert, 1988. Studenten und "Judenfrage" im Deutschen Kaiserreich. Die Entstehung einer akademischen Trägerschicht des Antisemitismus, Göttingen.

Katz, Jacob, 1980. From Prejudice to Destruction. Anti-Semitism, 1700-1933, Cambridge, Mass. 1980.

Katz, Jacob, 1983. Exclusiveness and Tolerance. Studies in Jewish-Gentile Relations in Medieval and Modern Times, West Orange, N.J.

Katz, Jacob, 1986. The Darker Side of the Genius: Richard Wagner's Anti-Semitism, London.

Katz, Jacob, 1994. Die Hep-Hep-Verfolgungen des Jahres I8rg, Berlin.

Kauders, Anthony, 1996. German Politics and the Jews. Düsseldorf and Nuremberg I9ro-33, Oxford.

Kushner, Toni, 1989. The Persistence of Prejudice: Antisemitism in British Society during the Second World War, Manchester.

Kushner, Tony, 1991. "The Social and Cultural Roots of Contemporary Antisemitism". Patterns of Prejudice 25, I8-3I.

Kushner, Tony, 1999. "Comparing Antisemitisms: A Useful Exercise?" i: Michael Brenner, Rainer Liedtke og David Rechter (red.), Two Nations: British and German Jews in Comparative Perspective, 9I-I09.

Lammers, Karl Christian, 1987. "Det fremmede element. Om antisemitisme i Danmark i mellemkrigstiden. Refleksioner over en tid og et fænomen", i: Den jyske Historiker 40, 84-97.

Langmuir, Gavin I., 1990a. History, Religion and Antisemitism, Berkeley.

Langmuir, Gavin I., I99ob. Toward a Definition of Antisemitism, Los Angeles.

Lauridsen, John T., 2000. "DNSAP og 'jødespørgsmålet' - en variation over et internationalt tema", i: Johnny Laursen u.a. (red.), I tradition og kaos. Festskrift til Henning Poulsen, København, II7-I49.

Lepsius, M. Rainer, r973. "Parteiensystem und Sozialstruktur. Zum Problem der Demokratisierung der deutschen Gesellschaft", i: G. A. Ritter (red.), Deutsche Parteien vor IgI8, Köln, 56-80.

Lichtblau, Albert, 1994. Antisemitismus und soziale Spannung in Wien und Berlin I867-19I4, Berlin.

Massing; Paul, 1949. Rehearsal for Destruction. A Study of Anti-Semitism in Imperial Germany, New York.

Messmer, Matthias, 1997. Sowjetischer und postkommunistischer Antisemitismus. Entwicklungen in Rußland, der Ukraine und Litauen, Konstanz.

Mosse, George, 1964. The Crisis of German Ideology. Intellectual Origins of the Third Reich, New York.

Nowak, Kurt, og Gérard Raulet (red.), 1994. Protestantismus und Antisemitismus in der Weimarer Republik, Frankfurt a.M.

Pickus, Keith H., I999. Constructing Modern Identities. Jewish University Students I8I5-I9I4, Detroit. 
Pohl, Dieter, 1997. "Die Holocaust-Forschung und Goldhagens Thesen", i: Vierteljabrshefte fuir Zeitgeschichte 45, I-48.

Poliakov, Leon, 1955-77. History of Anti-Semitism, London.

Pulzer, Peter, 1964. The Rise of Political Anti-Semitism in Germany and Austria, New York (rev. udgave London 1988).

Rahden, Till van, 1996. "Ideologie und Gewalt. Neuerscheinungen zur Geschichte des deutschen Antisemitismus im 19. und frühen 20. Jahrhundert", i: Neue Politische Literatur 4I, II-29.

Rahden, Till van, 1998. "Sprechen und Handeln im Breslauer Antisemitismus des Kaiserreichs", i: Österreichische Zeitschrift für Geschichtswissenschaften 9, 2I8-243.

Robertson, Ritchie, 1999. The "Jewish Question" in German Literature 17491939. Emancipation and its Discontents, Oxford.

Rohrbacher, Stefan, 1993. Gewalt im Biedermeier. Antijüdische Ausschreitungen in Vormärz und Revolution (I8I5-I848/49), Frankfurt a.M.

Rohrbacher, Stefan, og Michael Schmidt, 1991. Judenbilder. Kulturgeschichte antijüdischer Mythen und antisemitischer Vorurteile, Hamburg.

Rose, Paul Lawrence, 1990. Revolutionary Antisemitism in Germany from Kant to Wagner, Princeton.

Rosenberg, Hans, 1967. Große Depression und Bismarckzeit, Berlin.

Rürup, Reinhard, 1976. "Emanzipation und Krise - Zur Geschichte der „Judenfrage" in Deutschland vor 1890" i: Werner E. Mosse (red.), Juden itm Wilhelminischen Deutschland 1890-I9I4, Tübingen, I- 56 .

Rürup, Reinhard, 1986. "Das Ende der Emanzipation: Die antijüdische Politik in Deutschland von der "Machtergreifung" bis zum Zweiten Weltkrieg" i: Arnold Paucker et al. (red.), Die Juden im nationalsozialistischen Deutschland r933-1945, Tübingen, 97-II4.

Rürup, Reinhard, 1987. Emanzipation und Antisemitismus. Studien zur Judenfrage der bürgerlichen Gesellschaft. Frankfurt a.M. (første udgave Göttingen I975).

Rürup, Reinhard, I99I. "Sozialdemokratie und Antisemitismus im deutschen Kaiserreich" i: Micha Brumlik et al. (red.), Der Antisemitismus und die Linke, Frankfurt a.M., I7-31.

Rürup, Reinhard, 1998. "Der Fortschritt und seine Grenzen. Die Revolution von 1848 und die europäischen Juden", i: Dieter Dowe et al. (red.), Europa 1848 . Revolution und Reform, Bonn, 985-1005.

Rürup, Reinhard, og Thomas Nipperdey, 1987. "Antisemitismus - Entstehung, Funktion und Geschichte eines Begriffs" i: Reinhard Rürup, Emanzipation und Antisemitismus. Studien zur Judenfrage der bürgerlichen Gesellschaft, Frankfurt a.M. I987 (første udgave Göttingen 1975), I20-I44.

Schmuhl, Hans-Walter, 1992. Rassenhygiene, Nationalsozialismus, Euthanasie. Von der Verbütung zur Vernichtung "lebensunwerten Lebens" I890-1945, 2. opl., Göttingen.

Schoeps, Julius H. og Joachim Schlör, 1995. Antisemitismus. Vorurteil und Mythen, München. 
Schoeps, Julius H. (red.), I996. Ein Volk von Mördern: Die Dokumentation zur Goldhagen-Kontroverse um die Rolle der Deutschen im Holocaust, Hamburg.

Schwartz Lausten, Martin, 1992. Kirke og synagoge. Holdningen $i$ den danske kirke til jødedom og joder $i$ middelalderen, reformationstiden og den lutherske ortodoksi. København.

Schwartz Lausten, Martin, 2000. De fromme og jøderne. Forholdet mellem kristne og joder i Danmark i pietismens tid (ca. I700-I760). København.

Steinberger, Petra (red.), 200I. Die Finkelstein-Debatte, München.

Sterling, Eleonore, I950. "Anti-Jewish Riots in Germany in I819. A Displacement of Social Protest", i: Historia Judaica I2, 105-r42.

Sterling, Eleonore, 1969. Judenhaß - Die Anfänge des politischen Antisemitismus in Deutschland I8I5-1850, Frankfurt.

Strenge, Barbara, 1996. Juden im preussischen Justizdienst I8I2-I9I8. Der Zugang zu den juristischen Berufen als Indikator der gesellschaftlichen Emanzipation, München.

Suchy, Barbara, 1985. "The Verein zur Abwehr des Antisemitismus", i: Year Book of the Leo Baeck Instute 30, 67-103.

Tal, Uriel, I974. Christians and Jews in Germany. Religion, Politics and Ideology in the "Second Reich", (I870-I9I4), Ithaca.

Timm, Angelika, 1997. Hammer, Zirkel, Davidstern. Das gestörte Verhältnis der DDR zu Zionismus und Staat Israel, Bonn.

Vital, David, 1999. A People Apart: The Jews in Europe 1789-1939, New York.

Volkov, Shulamit, 1978. The Rise of Popular Antimodernism. The Urban Master Artisans $1873-1896$, Princeton, N.J.

Wagner, Thorsten, 2001a. "Ein vergebliches Unterfangen? Der Antisemitismus und das Scheitern des dänischen Nationalsozialismus"; i: Angelika Königseder, Hermann Graml og Juliane Wetzel (red.), Vorurteil und Rassenhaß. Antisemitismus in den faschistischen Bewegungen Europas, Berlin $275-296$.

Wagner, Thorsten, 200Ib. "Fællesskabets nationalisering og jødespørgsmålet $\mathrm{i}$ en liberal kultur. Jøderne i Danmark mellem inklusion og eksklusion" i: Uffe Østergaard og Cecilie S. Banke (red.), Folk og fallesskab. Trak af fallesskabstenkningen i mellemkrigstiden, København, 47-6I.

Walter, Dirk, 1999. Antisemitische Kriminalität und Gewalt. Judenfeindschaft in der Weimarer Republik, Bonn.

Walz, Rainer, 1995. "Der vormoderne Antisemitismus. Religiöser Fanatismus oder Rassenwahn?", i: Historische Zeitschrift 260, 719-48.

Wehler, Hans-Ulrich, 1987ff. Deutsche Gesellschaftsgeschichte, München.

Weiss, John, 1996. Ideology of Death: Why the Holocaust happened in Germany, Chicago.

Wippermann, Wolfgang, I997 "Wie die Zigeuner". Antisemitismus und Antiziganismus im Vergleich, Berlin.

Yahil, Leni, 1969. The Rescue of Danish Jewry. Test of a Democracy, Philadelphia. Yardeni, Miriam. 1990. Anti-Jewish Mentalities in Early Modern Europe, Lanham, MD. 